\title{
The 23rd International Seaweed Symposium: seaweed from tradition to innovation!
}

\author{
Stefan Kraan ${ }^{1}$ - Susan Løvstad Holdt ${ }^{2}$. Jeong Ha Kim ${ }^{3}$ \\ Revised and accepted: Published online: 26 August 2020 \\ (C) Springer Nature B.V. 2020
}

The 23rd International Seaweed Symposium (ISS) was held in Jeju, Republic of Korea, on April 28 to May 3, 2019, at the International Convention Centre. The ISS is a triannual congress held under the auspices of the International Seaweed Association (ISA; www.ISASeaweed.org). Starting from humble beginnings in 1952 with the First International Seaweed Symposium in Edinburgh, Scotland, with Dr. F.N. Woodward as chairman (Indergaard 2017), we are now almost 7 decades further with the 23rd Symposium in Korea. In 1952, almost 200 people attended from 21 different countries, and 53 papers were submitted; we now have peaked at over 850 registrants from 41 different countries, 22 mini symposia, 349 oral presentations, and 259 poster presentations (Fig. 1).

During the last decade, seaweeds in general have become very popular as they have such a wide and diverse application from raw material and aquaculture/IMTA to fertiliser and biostimulants, feed and animal health, food and human health to materials, fabric, pharma, biotechnology and carbon sequestration/ habitat restauration (Fig. 2). Coupling this to the Korea's long history and tradition of seaweed aquaculture and food use and the 23rd ISS was guaranteed to become a success. We are also happy to report that the exhibition/trade show is a growing part of the ISS which became very apparent at the Korean congress demonstrating the wide variety of

Stefan Kraan

stefan.kraan@theseaweedcompany.com

Susan Løvstad Holdt

suho@food.dtu.dk

Jeong Ha Kim

jhkbio@skku.edu

1 The Seaweed Company Blue Turtle, Mausrevagh Kilcoona, Headford Co., Galway H91 E09X, Ireland

2 National Food Institute, Danish Technology University, Copenhagen, Denmark

3 Department of Biological Sciences, Sungkyunkwan University, Suwon, Republic of Korea

seaweed use in everyday life. The link with the seaweed industry is of vital importance to the ISS concept and stimulates synergy and partnerships between academics and industry and provides vital important funding to be able to run these conferences.

Besides presenting the latest results in innovative research and novel applications using seaweeds as raw material, the ISS is also an excellent platform for academics (scientists and technologists), seaweed industry, SMEs, government and NGO officials to meet, exchange ideas, network and create partnerships or just meet old friends.

This theme of the 23rd ISS "Seaweed from Tradition to Innovation" refers to the long history of seaweed use in Korea, mainly cultivation and food use (Figs. 3 and 4), but this can be said for many maritime countries where documented seaweed used for feed and fertiliser application goes back many centuries. With over 600 abstracts submitted, the scientific program achieved the right balance between oral and poster presentations and provided all aspects of seaweed research to initiate meaningful discussions.

The program was developed by the National Organising Committee (NOC) with the help of the International Seaweed Association Council (ISAC). The NOC has performed a stellar job, and we would particularly like to thank Jeong Ha Kim (Chair of the NOC); Jang Kyun Kim (Secretary); Ga Youn Cho (Treasurer); Sung Min Boo and Hyung Geun Kim (Advisory Committee); Hwan Su Yoon, Myung Sook Kim, You Jin Jeon, Eon Seon Jin, Mi Sook Hwang and Woongghi Shin (Scientific Committee); and Han Gil Choi, Han Gu Choi, Young Sik Kim, Chang Geun Choi and Myung Gil Park (Program Committee).

There were five excellent key note speakers highlighting the diversity of subjects in seaweed research:

1) Sung Min Boo started off with the beautiful diversity of seaweeds around the Jeju Isle, the Island where the conference took place, with: "Beautiful and familiar seaweeds in Jeju Islands: diversity and distribution". 


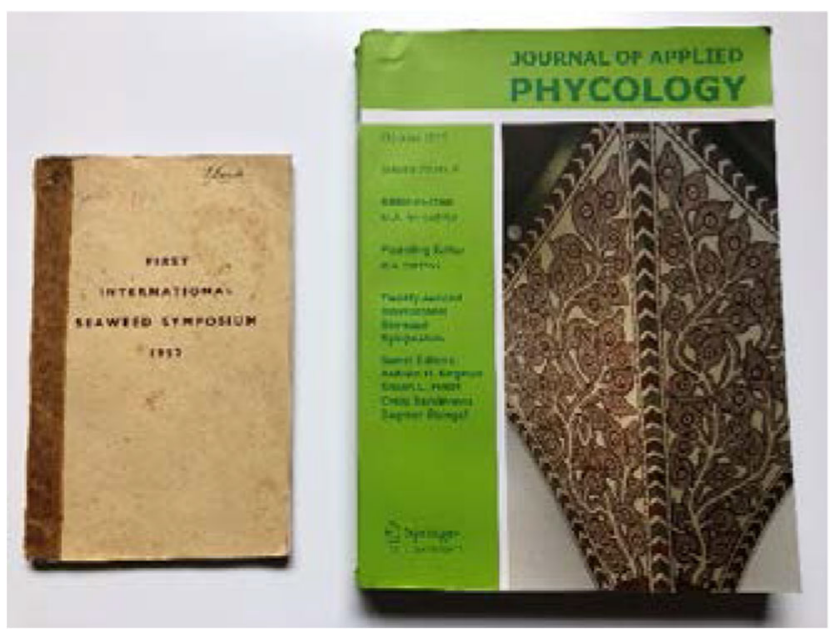

Fig. 1 Almost 7 decades of International Seaweed Symposium in proceedings

2) Olaf Kruse brought us back to a microscopic level with "Microalgae as sustainable photosynthetic green cell factories".

3) Elizabeth J. Cottier-Cook talked about the over reliance of non-native species for aquaculture in her presentation "The aquaculture and aliens paradox: Could the reliance of the seaweed aquaculture industry on non-native species lead to its' downfall?".

4) J. Mark Cock went to the core of seaweeds and spoke about molecular tools for cultivation in "Economic and genetic approaches to explore brown algal biology and support seaweed aquaculture".

5) Filipe Alberto stayed in the genetic realm and gave his perspective on "Using genetics to unravel the ecology and economic potential of the giant kelp Macrocystis pyrifera".

The overall program was divided into 22 mini symposia, 34 oral sessions, a special session on seaweed aquaculture, 7 student competition sessions, 4 parallel workshops and 2 poster sessions, besides a busy and well-organised social program. Literally, every possible subject, too many to name here, was covered. What became clear after an intensive week of presentations demonstrating novel cultivation technologies and new bioactive compounds, upscaling methodologies for extractions, unravelling genetics and discovering how to manipulate gene expression of certain compounds as well as upscaling cultivation systems and harvesting systems is that the seaweed community be it academic or industry is more alive and vibrant than ever before with a bright future ahead. It also establishes a firm and rooted framework for many ISS symposia to come and stay a leading light in dissemination of seaweed research based on almost 7 decades of experience.

Recently, the trade exhibition is becoming a solid part of the ISS highlighting the importance of exhibitors, trade and industry as a vital part of the seaweed community. It not only provides a hand-on experience for our delegates that are able to see taste and touch the variety of seaweed products but also fulfils a vital role as sponsors to make the ISS still the leading conference at a global level. Our appreciation goes out to all the exhibitors and sponsors that put in the effort to make this a great event!

The Social Program was well organised starting - as is tradition - on the Sunday night for all participants to meet and great old friends and make new ones while having a bite to eat and some drinks under the amazing sea views of Seogwipo with classical concert. Next day on Monday, we were in for a treat at the opening ceremony as a part of the Korean musical "Ho-oey" Story was performed. A very fitting musical as the story is about the Haenyeo, the traditional Korean free-diving women (Fig. 5).

We were also happy to see a new tradition of a special student night. A way for students to mingle under a relaxed atmosphere of Korean chicken, pizza and beer without their supervisors looking over their shoulders! It would be good to continue this in future symposia. Another initiative organised by the NOC was a phycology photo contest that delegates could choose the two best photos by putting small stickers on the displayed photos.

The symposium banquet took place in the open air at the Aldre Garden of the Seas Hotel and Resort close to the conference centre. Besides life traditional Korean music, we were also treated at some special Korean foods in buffet style. After the banquet and to the hosts' surprise, an impromptu trip to the local night club was organised with close to 100 people celebrating into the late hours.

The mid-symposium tour had many trips on offer combined in one tour in different orders. Amongst them is a visit to Seongsan Sunrise Peak, a designated UNESCO World Natural Heritage Site, consisting of a crater which was created over 100,000 years ago, followed by the Haenyeo Museum which preserves and passes down Jeju Haenyeo culture which is selected as UNESCO Cultural Heritage; the Manjanggul Cave, a special lava tunnel and designated natural monument; and the Gimnyeong Maze Park followed by Seogwipo Olle Market and Lee Jung Seop Street, where a famous Korean artist painted many Seogwipo scenes.

Normally on the Sunday before the 23rd ISS starts, the ISA Committee meets face-to-face to discuss and ISA matters and make decisions on the organisation in respect of the code of conduct, honorary members, website, elections of candidates, treasury report and monies spend, student travel, prizes, bids and proposals for the next conference, etc.

With the 23rd ISS, the mandate of three members expired: Jean-Paul Deveau (Canada), Ian Neish (Indonesia) and Masahiro Notoya (Japan). We thank them for their contributions and commitment and wish them well. Three new members joined the team: Helena Abreu (Portugal), Jeong Ha Kim 
Fig. 2 Dress designed by $\mathrm{Lu}$ Zhou 周露 from Laminaria japonica leaves displayed at the 23rd ISS in Jeju, Republic of Korea (left) and fabric made with seaweed by Lu Zhou on the right
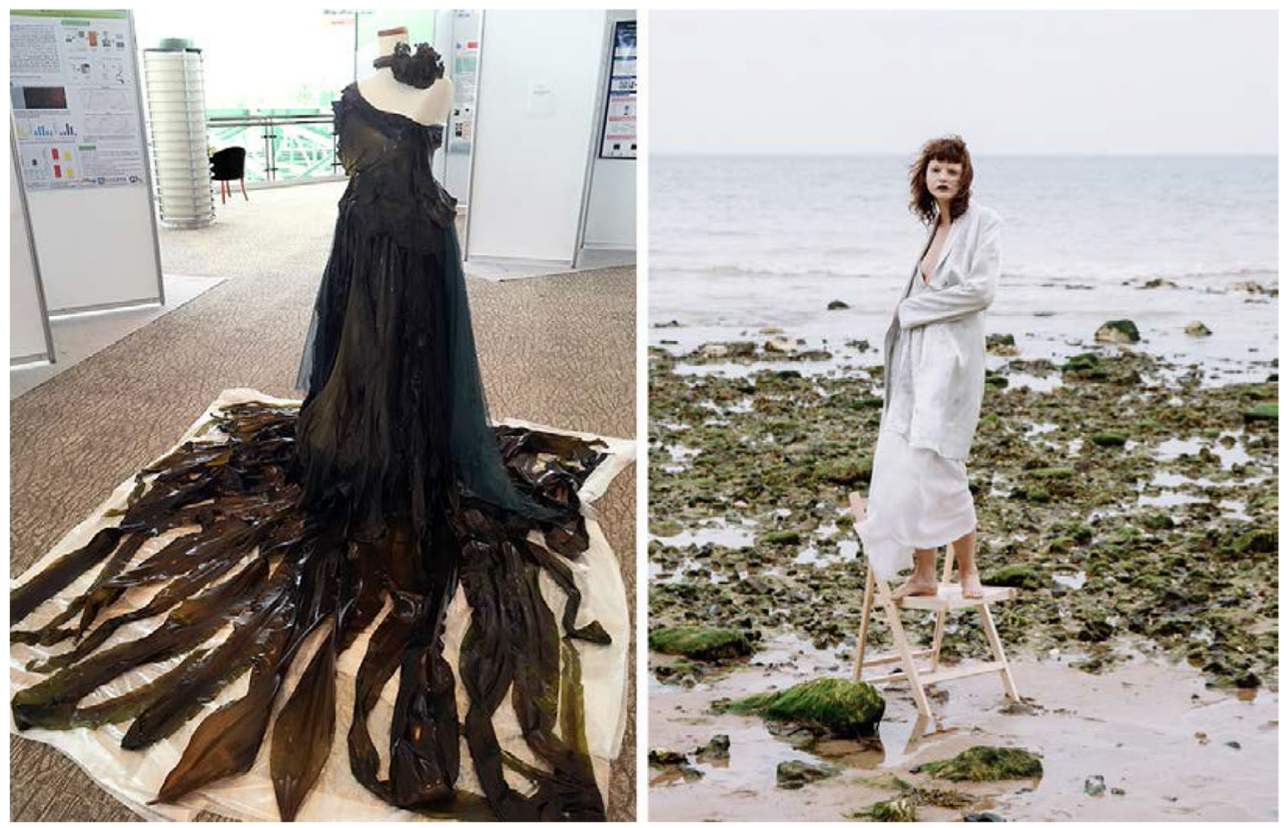

(Korea) and Jaime Zamorano (Chile), and we extend a warm welcome to them. Due to personal circumstances, Gonzalo Soriano (Argentina) had to step down as treasurer, and Erick Ask (USA) has taken over the role as treasurer. We wish Gonzalo well and thank him for his valuable contribution and keeping the organisation in financial health.

For the period 2019-2022, Daniel Robledo (Mexico) becomes President, Helena Abreu (Portugal) Vice-President, Erick Ask (USA) Treasurer, Susan Holdt (Denmark) Secretary General and Stefan Kraan (past-President). Over the last 3 years, rather than working with a hierarchical system meeting once every 3 years, the executive decided to work as a team. Regular committee meetings through Skype (2-3 times a year) were held (great fun with different time zones from Japan to the USA), increasing in frequency closer to the 23rd ISS. This seems to work very well, keeping the flow of communication and decision-making going at a smooth pace. Several changes have been made (amongst them the code of conduct) to renew the organisation into a modern digital entity, for one, a good functioning website with modern logo and look integrating social media with web functionality. This is an ongoing work and is expanded all the time with industry and academic participation to add infographics on seaweed resources per country, announcements, courses, online phycology classes, etc. This goes in tandem with the ISA project platform hosted through the Danish Technology University for file sharing, timelines, deadlines and milestones. The committee members now have tasks assigned to constructively build the organisation to maintain its leading position at a global level.

The organisation is in good financial health. A big thank you to our past treasurer Gonzalo Soriano for bringing in industry funding to be able to expand the organisation with an online presence and being able to establish the Maxwell Doty fund. This new fund was needed as the generous gift given by the University of British Columbia in 1989 at the 13th ISS had run out.

Being a member of the ISA (which happens automatically for 3 years if you attend an ISS meeting) will automatically

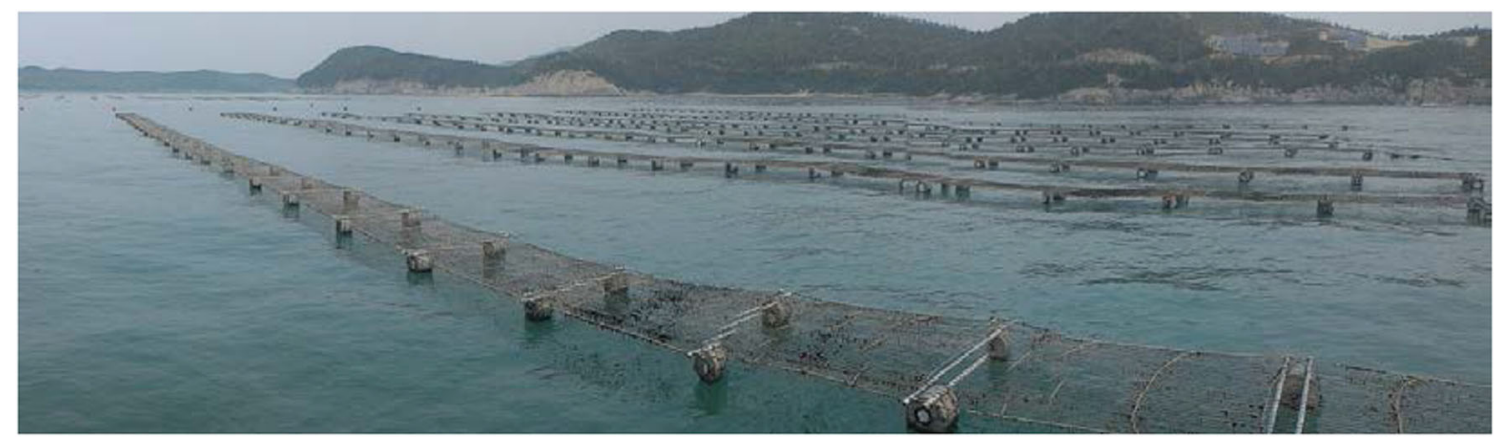

Fig. 3 Seaweed aquaculture farms near Wando, Korea 


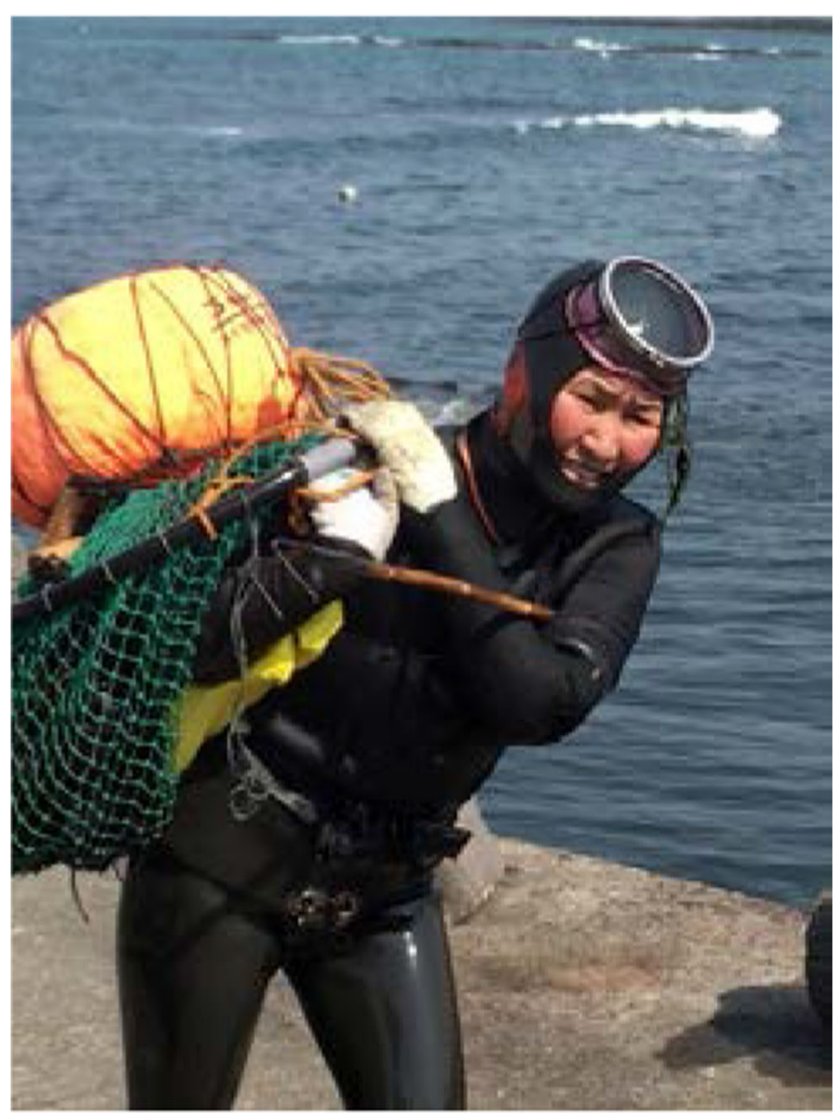

Fig. 4 Traditional Haenyeo on Jeju Island collecting seaweed, cephalopods and shellfish by free diving

allow you to access all areas of the ISA website. This will expand soon with phycology courses and workshops and travel bursaries. Furthermore, you will have free online access to the Journal of Applied Phycology in which the ISS Proceedings are published in a special issue. Since the 22nd
ISS in Copenhagen, we have now modernised operation manuals to run and operate an International Seaweed Symposium as well as for bidding criteria. The organisation of the 24th ISS in Hobart Tasmania is well underway, and bids are open to host the 25th ISS in 2025.

We have positively addressed the gender balance with 3 women serving on the council and put in action the first female President, Helena Abreu, taking up the role in 2022. Furthermore, we have attracted a younger generation into the committee to ensure its vibrancy and survival for years to come.

\section{Maxwell S. Doty Award}

At the closing ceremony on Friday, May 3, the newly established Maxwell S. Doty awards were presented.

What is the Maxwell Doty award? This award was established to honour the life and the contributions to phycology of Dr. Maxwell S. Doty (1916-1996) (Fig. 6). Dr. Doty taught at the University of Hawai' $i$, Department of Botany for over 40 years. He was two times President of the ISA and was the researcher instrumental in developing Eucheumoid seaweed cultivation for the carrageenan industry, creating many jobs all over the world and in particular for the Indo-Pacific coastal communities. His research greatly helped to advance the science of marine agronomy worldwide. It is estimated that the commercial seaweed industry that he was primarily responsible for developing in the Philippines is worth approximately US $\$ 100$ million annually. The Max Doty award issued by the ISA is for outstanding research in applied phycology. There are three awards of US\$1500, US\$ 1000 and US\$ 500.

This symposium's awards were:

1st Prize: Louis Graf (Korea) - Genome sequencing and population genomic analysis provide insights into

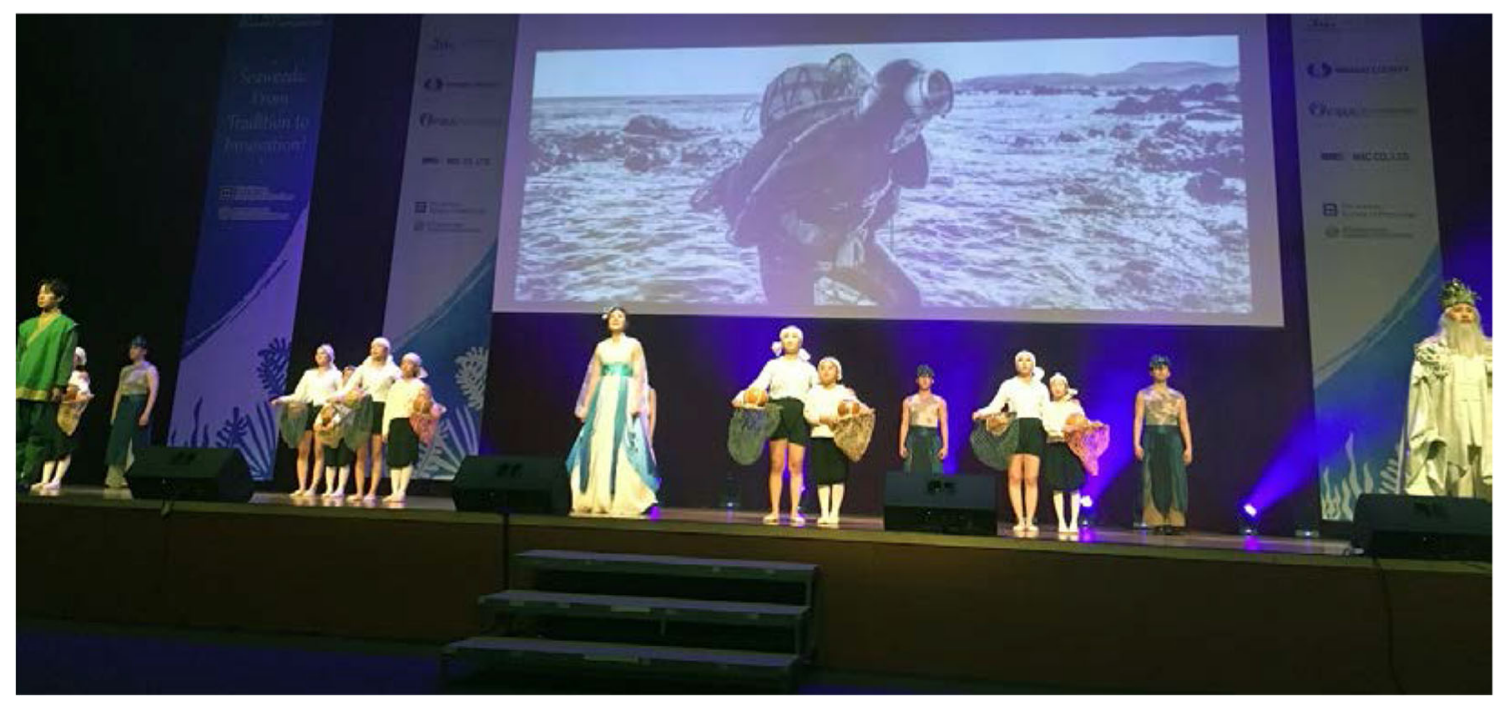

Fig. 5 Musical performance of Jeju's traditional Haenyeo story at the opening ceremony 
domestication and adaptation to new environments in the kelp Undaria pinnatifida.

2nd Prize: Daniel Liesner (Germany) - Transgenerational temperature effects in the kelp Laminaria digitata.

3rd Prize: Stephanie Revilla-Lovano (Mexico)Physiological responses and growth of the seaweed Ulva sp. under changing cultivation conditions in pilot and land-based ponds.

\section{Student Awards}

The best student presentation awards are given for outstanding student papers presented at the 23rd ISS as determined by the Student Award Committee. The funding for these awards has been kindly provided in part by the Scottish Association for Marine Science (SAMS).

Best student oral presentations:

1. Daniel Liesner (Germany): Transgenerational temperature effects in the kelp Laminaria digitata.

2. Jihoon Jo (Korea): SoEM: A novel PCR-free biodiversity assessment method based on small organelle-enriched metagenomics.

3. Chun-Ju Sung (Taiwan): Fucoidan from brown algae reduces cell migration in human bladder cancer T24 cells.

4. Shahlizah Sahul Hamid (Japan): Effect of blanching on the metabolites profiling in Wakame and Mekabu.

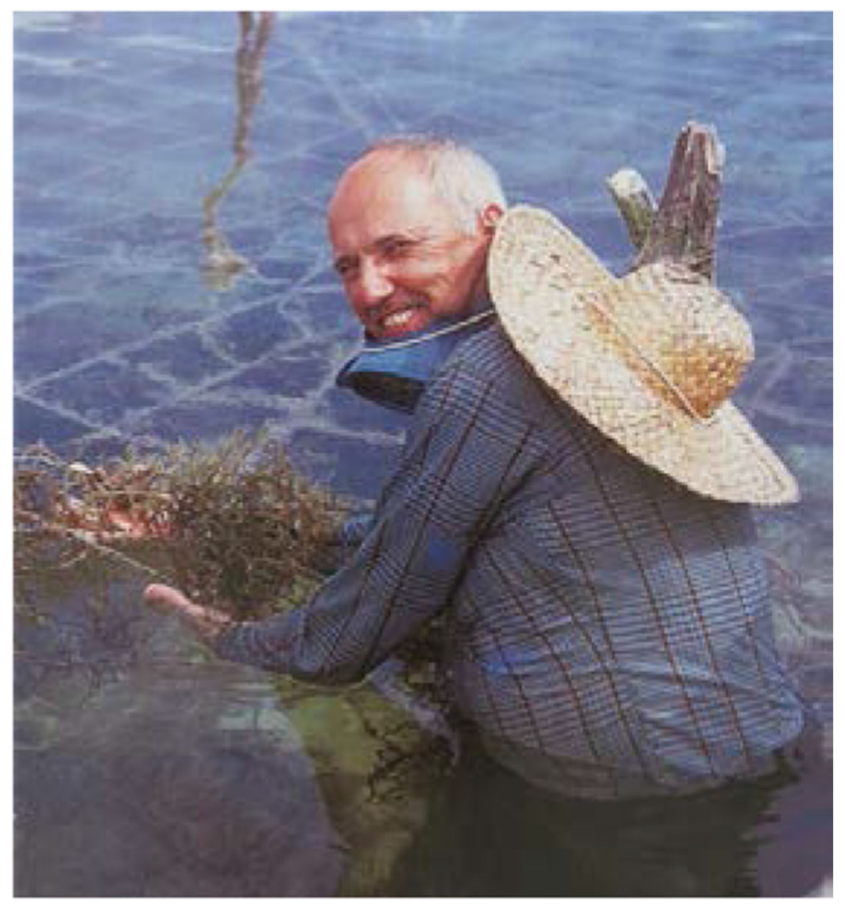

Fig. 6 Maxwell S. Doty in the field working on Eucheuma J. Agardh
5. Soyeon Choi (Korea): Deformity of benthic diatom as biomarkers of marine environment.

6. Sookkyung Shin (Korea): Effects of stocking density on productivity and nutrient removal of Gracilaria vermiculophylla in Paralichthys olivaceus biofloc effluent.

7. Chung Hyun Cho (Korea): Evolutionary dynamics of mitogenomes in Cyanidiophyceae (Rhodophyta).

Best student poster presentations:

1. Dajeong Lee (Korea): NADPH oxidase-mediated oxidative burst plays a key role in resistance to pathogen attacks in red alga Pyropia tenera.

2. Chung Hyeon Lee (Korea): The effect of climate change on growth rate and chain-forming capacity of the Alexandrium pacificum.

3. Gerli Albert (Estonia): Could ocean acidification influence epiphytism? A comparison of carbon-use strategies between Fucus vesiculosus and its epiphytes in the Baltic Sea.

4. Thilina U. Jayawardena (Korea): Sargassum horneri ethanol extract inhibits fine dust induced inflammation via Nrf2/HO-1 signaling pathway in RAW 264.7 macrophages.

5. Eui Jeong Han (Korea): 5-bromo-3,4dihydroxybenzaldehyde from Polysiphonia morrowii suppress the IgE-mediated allergic response in mast cell and passive cutaneous anaphylaxis animal mouse model.

6. Jose Avila Peltroche (Korea): Factors affecting survival and cell division during protoplast culture of Undaria pinnatifida sporophyte.

Our thanks and appreciation to the different committees judging posters and oral presentations. Not an easy task with so many posters and presentations of high quality.

The Springer Prize kindly funded by Springer with a book voucher for Springer Scientific books was awarded in no particular order to:

Kwon Mo Yang: Recovery of kelp forest: two case studies in Korea

Shareen A. Abdul Malik: Chemical defence by allelopathic active metabolites on the surface of cultivated Mexican Rhodophyta Halymenia floresii against biofouling

Lei Wang: Protective effect of sulphated polysaccharides from Hizikia fusiforme against ultraviolet B-induced skin photoaging

It also gave us great pleasure to announce the award of a lifetime Honorary membership of the International Seaweed Association to Prof Michael D. Guiry (Fig. 7). Not only did 


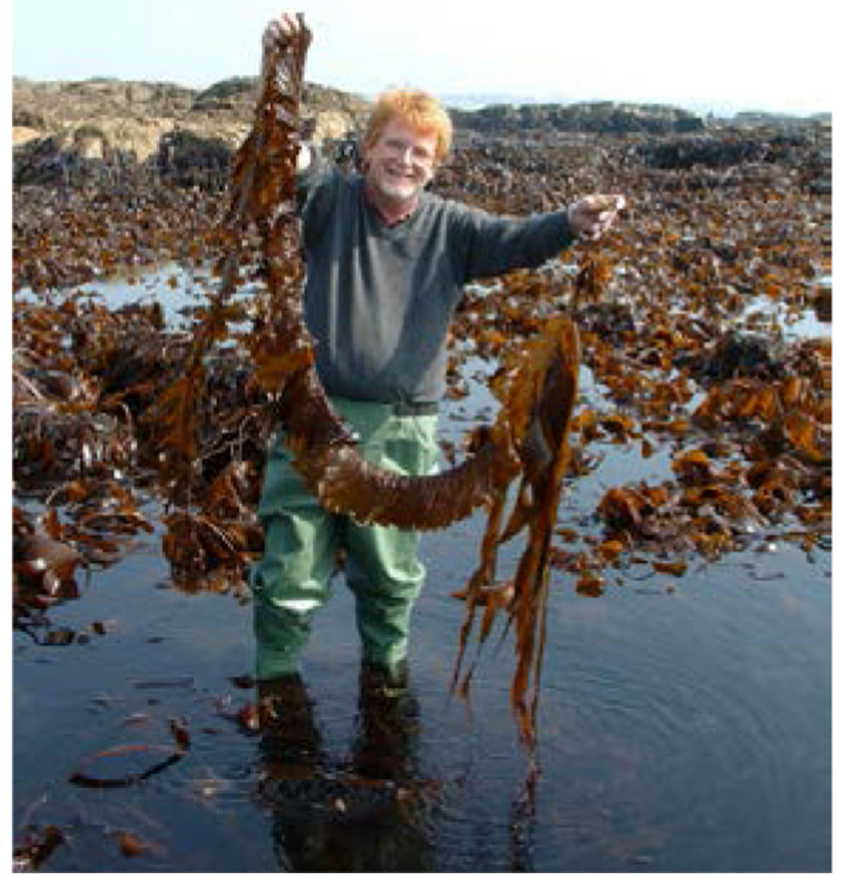

Fig. 7 Prof Michael Guiry in his element collecting Alaria esculenta Greville at the shores of An Spidéal Co. Galway, Ireland

Prof Guiry contribute greatly to the ISA in the early days as web master of the first websites for the ISA for many years where he was responsible for running and maintaining the digital part of ISA in the early years. However, probably his greatest achievement is the establishment and maintaining of Algaebase (www. Algaebase.org), a taxonomic database on algae which is a major asset for all phycologists. Michael Dominic Guiry was born at Youghal, Ireland, in 1949. He obtained Ph.D. in 1975 at the University of London and DSc in 1988. He was a lecturer in Botany, University College, Galway/National University of Ireland Galway (1979-1989), Associate Professor (19891996), Professor of Botany (1996-2009), Visiting Research Fellow, University of Melbourne, Australia (1987-88); James Professor in Pure and Applied Sciences, St Francis Xavier University, Nova Scotia, Canada (1989), and Director of the Ryan Institute, National University of Ireland, Galway (19962009).

He authored "A Consensus and Bibliography of Irish Seaweeds" (Guiry 1978) and co-authored "Seaweed Resources in Europe: Uses and Potential" (Guiry and Blunden 1991), "Check-list and Atlas of the Seaweeds of Britain and Ireland" (Hardy and Guiry 2003, 2006), "Seaweeds-A colour identification guide to seaweeds of the World" (Braune and Guiry 2011) and "A Catalogue of Irish Seaweeds" (Guiry 2012) as well as more than 265 research publications and articles on taxonomy, life histories, biodiversity, photoperiodism, molecular biology and commercial utilisation of marine and terrestrial algae. Several algal species have been named after him, e.g. Guiryella Huisman \& Kraft, with one species Guiryella repens Huisman et Kraft from western and southern Australia; Cordylecladia guiryi from Sicily; Gloiocladia guiryi from Pacific Russia; Fucus guiryi from the north-eastern Atlantic (was a variety of Fucus platycarpus); and Meredithia guiryorum G.W.Saunders \& C.W.Schneider from Lord Howe Island, Australia, named for Michael \& Wendy Guiry.

Unfortunately, all great things come to an end, and the 23rd ISS in Jeju Island Republic of Korea was no exception. We had wonderful week of scientifically stimulating presentations, traditional use of seaweed, new applications and innovative solutions in many fields of research in parallel with the great hospitality and Korean style entertainment through the social

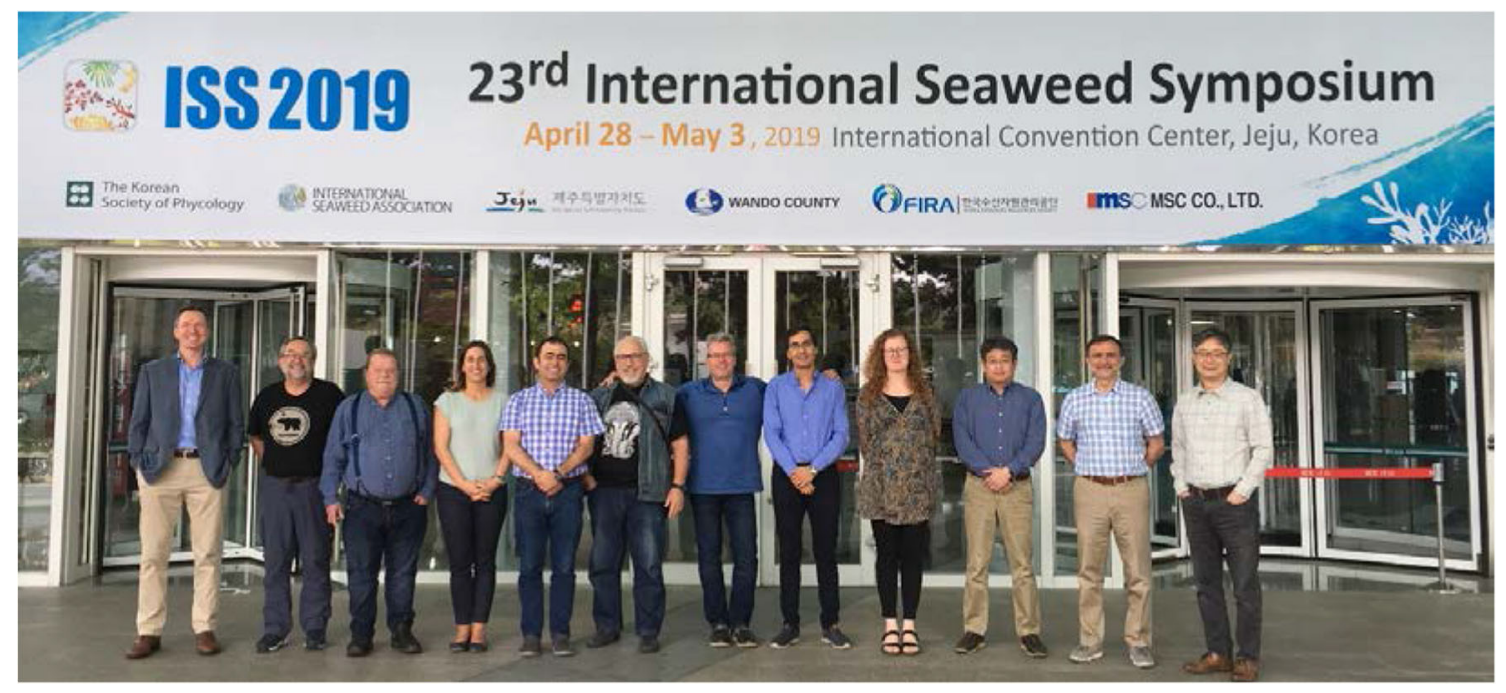

Fig. 8 ISAC members photographed after the meeting on April 28, 2019 
program. The ISA would like to extend their appreciation to the NOC for organising such a wonderful and special congress. Also, the NOC would like to thank all the participants and sponsors for visiting Korea and making the ISS-2019 a successful and wonderful meeting (Fig. 8).

We are looking forward to doing it all again and meet up at the 24th ISS at Australia's southernmost state, Tasmania. The Symposium will be held in Tasmania's capital, Hobart, from Sunday 13 to Friday 18, February 2022. The theme for this symposium will be "Seaweed in a changing world".

\section{References}

Braune W, Guiry MD (2011) Seaweeds. A colour guide to common benthic green, brown and red algae of the world's oceans. A.R.G. Gantner, Ruggell, Liechtenstein
Guiry MD (1978) A consensus and bibliography of Irish seaweeds. Bibliotheca Phycologia, vol 44. J. Cramer, Vaduz

Guiry MD (2012) A catalogue of Irish seaweeds. A.R.G, Gantner, Ruggell, Liechtenstein

Guiry MD, Blunden G (eds) (1991) Seaweed resources in Europe: uses and potential. Wiley, Chichester

Hardy FG, Guiry MD (2003) A check-list and atlas of the seaweeds of Britain and Ireland. British Phycological Society, London

Hardy FG, Guiry MD (2006) A check-list and atlas of the seaweeds of Britain and Ireland, 2nd edn. British Phycological Society, London

Indergaard M (2017) The First International Seaweed Symposium held in Edinburgh, UK, 1952: applied seaweed science coming of age. J Appl Phycol 29:2165-2173

Publisher's note Springer Nature remains neutral with regard to jurisdictional claims in published maps and institutional affiliations. 